\section{SCIENTIFIC TRAINING OF ATHLETES' CORE STRENGTH IN COMPETITIVE SPORTS}

\author{
TREINO CIENTÍFICO DA FORÇA DO COREDE ATLETAS EM ESPORTE COMPETITIVO \\ ENTRENAMIENTO CIENTÍFICO DE LA FUERZA DEL COREDEATLETAS EN DEPORTE COMPETITIVO
}

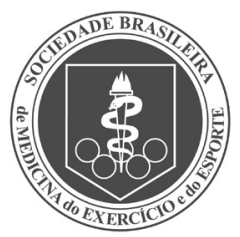

Original Article

Artigo Original Artículo Original
Changfeng Ning 1 (ID

(Physical Education Professional)

1. Department of Physical

Education, Yancheng Institute of

Technology, Jiangsu, China.

\section{Correspondence:}

Changfeng Ning

Jiangsu, China. 224051

ningcfsci@126.com

\begin{abstract}
Introduction: The role of core strength is to stabilize the core part of the human body, control the movement of its center of gravity and transmit the strength of the upper and lower limbs. The significance of core strength in competitive sports training is very important Objective: To discuss the importance of core strength training in competitive basketball, analyzing the improvement of athletes'basketball skills and physical confrontation ability after core training. Methods: We select several competitive basketball players who have no history of injury. We divided them into a control group and a test group. The control group did not perform core strength training, and the test group received core strength training. Results: After core strength training, the test group was better than the control group in shooting technique, physical confrontation, technical movement, and other aspects. Conclusion: Core strength training can help improve basketball competitive ability. Level of evidence ll; Therapeutic studies - investigation of treatment results.
\end{abstract}

Keywords: Basketball; Strength Training; Competitive Behaviors; Sports.

\section{RESUMO}

Introdução: A força do core tem o papel de estabilizar a parte central do corpo humano, controlar o movimento de seu centro de gravidade e transmitir a força dos membros superiores e inferiores. A força do core é significativamente importante para o treinamento em esportes a nível competitivo. Objetivo: Dicutir a importância do treinamento da força do core no basquete de nivel competitivo, analisando a melhora na habilidade dos atletas no esportee sua capacidade de confrontação física após esse treinamento. Métodos: Selecionou-se vários jogadores de basquete de nível competitivo que não têm histórico de lesões. Eles foram divididos em um grupo controle e um grupo teste. O grupo controle não recebeu treinamento da força do core, enquanto o grupo teste recebeuesse treinamento. Resultados: Depois do treino do core, o grupo teste apresentou melhores resultados do que o grupo controle em técnica de arremesso, confrontação física, movimento técnico, e outros aspectos. Conclusão: O treinamento de força do core pode ajudar a aprimorar a habilidade no basquete de nível competitivo. Nível de evidência ll; Estudos terapêuticos - investigação de resultados de tratamento.

Descritores: Basquetebol; Treinamento de Força; Comportamento Competitivo; Esportes.

\section{RESUMEN}

Introducción: La fuerza del core tiene el papel de estabilizar la parte central del cuerpo humano, controlar el movimiento de su centro de gravedad y transmitir la fuerza de los miembros superiores e inferiores. La fuerza del core es significativamente importante para el entrenamiento en deportes a nivel competitivo. Objetivo: Discutir la importancia del entrenamiento de la fuerza del coreen el básquet de nivel competitivo, analizando la mejoría en la habilidad de los atletas en el deportey su capacidad de confrontación física después de ese entrenamiento. Métodos: Se seleccionaron varios jugadores de básquet de nivel competitivo que no tienen antecedentes de lesiones. Ellos fueron divididos en un grupo control y un grupo prueba. El grupo control no recibió entrenamiento de la fuerza del core, mientras que el grupo prueba recibió ese entrenamiento. Resultados: Después del entrenamiento del core, el grupo prueba presentó mejores resultados que el grupo de control en técnica de lanzamiento, confrontación física, movimiento técnico y otros aspectos. Conclusión: El entrenamiento de fuerza del core puede ayudar a mejorar la habilidad en el básquet de nivel competitivo. Nivel de evidencia ll; Estudios terapéuticos - investigación de resultados de tratamiento.

Descriptores: Baloncesto; Entrenamiento de Fuerza; Conducta Competitiva; Deportes.

\section{INTRODUCTION}

Measuring the effect of strength training is mainly reflected in three aspects. The first is absolute power. The maximum amount of force stimulated by the body's function when the muscle undergoes the maximum voluntary contraction. The second is short power. Muscle contraction speed and ability to exert force. The third is strength endurance. The body's ability to fight fatigue. The leading strength training methods currently used at home and abroad mainly include the following: unbalanced equipment training, selective training, elastic band training, skateboard training, and rope pulley training. 'These training belong to the core muscle group strength training that transitions from stable to unstable and functionally restricted conditions. In basketball, endurance strength and fast strength, the two physical strength qualities, have a more obvious effect on competition. These two forces should also be based 
on the maximum strength of the body. The reasonable use of strength training methods in basketball training is conducive to learning basketball players'technical movements and correcting technical movement errors. This can strengthen the effect of competitive basketball training.

\section{METHOD}

We selected 30 college students as experimental subjects (Table 1). The article divides them equally into the experimental group and the control group. The experimental group adopts training methods with core strength as the main body. The control group used the traditional heavy load training method. ${ }^{2}$ The entire cycle is ten weeks. Before the experiment, 30 people were tested for physical fitness, vertical jump height, upper and lower limb strength, and other indicators. The whole experiment was carried out because there was no basic difference between the two groups.

In the basic training content of comprehensive strength, the training program of the experimental group has been added to the training program of an emergency stop jump shot, breakthrough, change of direction in the air, competitive confrontation, and other basketball skills training. ${ }^{3}$ The experiment aims to strengthen the coordination and stability of the athlete's body to stabilize the athlete's body posture in the confrontational movement. The purpose is to improve the competitive level of basketball players better.

Table 1. General information.

\begin{tabular}{c|c|c|c|c|c}
\hline Athlete & $\begin{array}{c}\text { Number of } \\
\text { people }\end{array}$ & Age (age) & Height $\mathbf{( c m )}$ & Training years & Weight (kg) \\
\hline Test group & 15 & $18.4 \pm 0.67$ & $189.7 \pm 4.28$ & $5.2 \pm 0.21$ & $79.5 \pm 4.49$ \\
\hline $\begin{array}{c}\text { Control } \\
\text { group }\end{array}$ & 15 & $18.5 \pm 0.59$ & $188.4 \pm 5.17$ & $5.0 \pm 0.85$ & $78.4 \pm 5.23$ \\
\hline
\end{tabular}

\section{The experimental group training program}

Core strength training should follow the principle of gradual training. Comprehensive training is scientific training that combines muscle strength training and weight training combined with biomechanics. The training volume and intensity of core strength training need to be controlled under the standard of athlete's fatigue. ${ }^{4}$ The specific implementation plan is as follows:

Supine buttocks and leg lift training: The purpose of this training method is to exercise the athlete's rectus abdominis, gluteus maximus, and other muscle groups. The training method is to place your hands on both sides of the passive body as support and bend the upper and lower legs to an angle of 120 degrees. Place the top of the hip joint so that the head, chest, abdomen, hips, and thighs are in a straight line. Do kicks on one leg, staggering the two legs. Train each group to do about 20-40.

\section{The content of the training items of the control group}

The main training contents selected by the control group were squats, leapfrogs, bench press, push-ups, double-headedness, weight-bearing squats, weightlifting, lifting, and so on. There is no significant difference between the training time and intensity settings and the experimental group.

\section{The training effect test standard of the control group}

T-run sensitivity test mainly reflects the athlete's speed, flexibility, and reaction ability under emergency stop and acceleration. In this test (Figure 1), the athlete starts from point $A$ after hearing the start command, accelerates, and runs until point $B$ touches the sign bucket at point $B$ and then runs to point $C$ to touch the sign bucket. ${ }^{5}$ The athlete then ran to the $D$ point to touch the marking bucket and then back to the $B$ point to touch the marking bucket. Finally, return to the starting point at point $A$, and the timing ends.

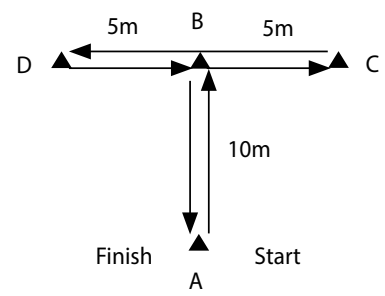

Figure 1. T-run sensitivity test.

In the jump shot test, each test athlete has 20 shots. The shots flow out of hand in the five shooting points distributed 5-6 meters away from the basket. When shooting, the standard shooting posture is uniformly used for two-step emergency stop jumpers to shoot. ${ }^{6}$ After the projection is over, the number of hits and the hit rate of the athletes are counted. Before and after training, each person tested the projection three times and took the best result.

\section{Motor skill ability assessment output}

We establish a set of fuzzy association rules for the evaluation of sports skills and abilities. Combining pattern recognition and big data analysis methods to realize the optimization of sports skills and ability assessment. The feature distribution set of segmented fusion of sports skill ability assessment is:

$\left\{\begin{array}{l}\omega=\omega(t)^{*} \omega_{\text {start }} k \geq \alpha \\ \omega=\omega(t)^{*} \frac{1}{\omega_{\text {end }}} k<\beta\end{array}\right.$

The decomposition form is expressed as:

$$
\text { s.t. } \sum_{(i, j) \in E} \hat{g}_{i j}^{c}-\sum_{j \in V} \sum_{(j, i) \in E} g_{j i}^{c}=T \sigma_{i}^{c}, \forall i, c
$$

$$
\left(\sum_{c \in C} \sum_{(i, j) \in E} e_{i}^{t} \hat{g}_{i j}^{c}+\sum_{c \in C} \sum_{j \in V} \sum_{(j, i) \in E} e_{i}^{r} g_{j i}^{c}\right) T \leq E_{i}, \forall i
$$

We use $\Delta M_{i j}(i=1, D ; j=1, N)$ to denote the contribution of the evaluation of sports skills and abilities. Then we construct the optimal decision function for the evaluation of sports skills. ${ }^{7}$ Calculate the independent random distribution variable of the statistical sample sequence of sports skill ability to obtain the association rule function of the sports skill ability evaluation as:

$$
\Delta M_{i j}=y_{i j}\left(B_{i}-A_{i}\right)
$$

Fuzzy association rules scheduling algorithm is used to realize the evaluation of sports skills. The evaluation results are:

$$
\tilde{\omega}_{k}^{i}=\tilde{\omega}_{k-1}^{i} \frac{p\left(z_{k} / \tilde{x}_{k}^{i}\right) p\left(\tilde{x}_{k}^{i} / x_{k-1}^{i}\right)}{q\left(\tilde{x}_{k}^{i} / x_{k-1}^{i}\right)}
$$

We use the field-habituation quantitative analysis method to obtain the optimized predictive value of the sports skill ability evaluation:

$$
x\left(t_{n+1}\right)=X_{m+1}(m)
$$




\section{RESULTS}

The results show that after ten weeks of training, the experimental and control groups have significant increases in the maximum strength of the lower limbs. However, there is no significant difference between the two groups. This indicates that the core strength training method and the traditional high-load training method have improved. There is no significant difference in the effect of lower limb strength (Table 2). Literature verification can also prove that heavy-load training can strongly stimulate the nervous system. This will increase the number of activated motor units to increase the contraction strength of human muscles. When athletes perform heavy training, the motor nerve center of the cerebral cortex will send out more concentrated high-frequency pulses. These high-frequency pulses can effectively stimulate the muscle fibers in the body. Exercise allows most muscle fibers to participate in the exercise and reserves more powerful kinetic energy for the muscles. After training, the shortening of the vertical flight time between the experimental group and the control group also reached the standard of significant difference. ${ }^{8}$ It can be seen that the more scientific core strength training enhances the vertical jump ability of basketball players more obviously. In the T-shaped sensitivity level test results, it can be found that the sensitivity levels of the experimental group and the control group have improved to varying degrees after training. There are also significant differences in the training effects between the two groups. There is also a significant difference in improving the experimental group's training performance in non-confrontational and confrontational jump shots.

\section{DISCUSSION}

In basketball, most athletes are taller. Therefore, the players' bodies are often unstable during the fierce competitive confrontation in the game. Basketball competition requires athletes to move and change their bodies flexibly. Therefore, athletes are required to have higher

Table 2. Comparison table of training results.

\begin{tabular}{|c|c|c|c|c|}
\hline \multirow[b]{2}{*}{ Index } & \multicolumn{2}{|c|}{ Test group } & \multicolumn{2}{|c|}{ Control group } \\
\hline & $\begin{array}{c}\text { Before } \\
\text { training }\end{array}$ & $\begin{array}{c}\text { After } \\
\text { training }\end{array}$ & $\begin{array}{c}\text { Before } \\
\text { training }\end{array}$ & $\begin{array}{c}\text { After } \\
\text { training } \\
\end{array}$ \\
\hline $\begin{array}{c}\text { Maximum strength of } \\
\text { lower limbs }(\mathrm{kg})\end{array}$ & $141.8 \pm 14.3$ & $182.3 \pm 23.7$ & $142.5 \pm 26.4$ & $175.7 \pm 25.8$ \\
\hline Approach height (m) & $3.15 \pm 0.10$ & $3.19 \pm 0.08$ & $3.23 \pm 0.05$ & $3.24 \pm 0.05$ \\
\hline Vertical jump in place (m) & $3.05 \pm 0.27$ & $3.13 \pm 0.31$ & $3.08 \pm 0.42$ & $3.09 \pm 0.39$ \\
\hline $\begin{array}{l}\text { Number of consecutive } \\
\text { jumps in } 15 \text { seconds }\end{array}$ & $14.68 \pm 1.03$ & $15.8 \pm 1.45$ & $14.71 \pm 0.89$ & $15.3 \pm 1.17$ \\
\hline T-sensitivity test (s) & $9.21 \pm 1.05$ & $8.29 \pm 0.96$ & $9.23 \pm 1.17$ & $9.05 \pm 1.23$ \\
\hline Jump shot percentage (\%) & $51.4 \pm 3.2$ & $79.8 \pm 3.6$ & $52.3 \pm 3.3$ & $59.2 \pm 3.4$ \\
\hline Hit rate against jump shots (\%) & $32.4 \pm 2.5$ & $51.3 \pm 3.1$ & $32.7 \pm 3.4$ & $38.2 \pm 4.8$ \\
\hline \multirow{2}{*}{ index } & \multicolumn{2}{|c|}{$\begin{array}{l}\text { Intra-group } \\
\text { comparison }\end{array}$} & \multicolumn{2}{|c|}{$\begin{array}{c}\text { Comparison } \\
\text { between groups }\end{array}$} \\
\hline & test group & $\begin{array}{l}\text { Control } \\
\text { group }\end{array}$ & $\begin{array}{l}\text { Before } \\
\text { training }\end{array}$ & $\begin{array}{l}\text { Significant } \\
\text { difference }\end{array}$ \\
\hline $\begin{array}{l}\text { Maximum strength of } \\
\text { lower limbs }(\mathrm{kg})\end{array}$ & $P<0.01$ & $P<0.01$ & $P>0.05$ & $P<0.05$ \\
\hline Approach height (m) & $P<0.05$ & $P>0.05$ & $P>0.05$ & $P<0.05$ \\
\hline Vertical jump in place (m) & $P>0.05$ & $P>0.05$ & $P>0.05$ & $P<0.05$ \\
\hline $\begin{array}{l}\text { Number of consecutive } \\
\text { jumps in } 15 \text { seconds }\end{array}$ & $P<0.01$ & $P<0.01$ & $P>0.05$ & $P>0.05$ \\
\hline T-sensitivity test (s) & $P<0.01$ & $P<0.05$ & $P>0.05$ & $P<0.05$ \\
\hline Jump shot percentage (\%) & $P<0.01$ & $P<0.05$ & $P>0.05$ & $P<0.01$ \\
\hline Hit rate against jump shots (\%) & $P<0.01$ & $P<0.01$ & $P>0.05$ & $P<0.01$ \\
\hline
\end{tabular}

control over the stability of the body. The research results show that core strength training can effectively improve the coordination and balance of athletes. ${ }^{9}$ This can effectively improve the movement speed of the athletes' limbs and better ensure that the athletes complete the tactical movements of basketball competition with high quality.

Another important technical requirement of basketball is the accuracy requirement. Basketball shooting, dribbling, passing, and other technical movements require athletes to have precise and delicate wrist and finger movement control and proficiency. In addition, the level of physical strength is also the hardware support for completing this series of competitive actions. When the strength level is improved, athletes can complete high-intensity and difficult aerial movements with high stability. ${ }^{10}$ Content such as three-point shots, long passes, etc. Traditional strength training pays more attention to the high-intensity, high-load pressure of the limbs. But core strength training focuses on the combination of limb strength and core trunk strength training. Through comprehensive physical strength training, the overall coordination of athletes can be better improved. The main body's torso can more effectively transmit power to the limbs so that the athlete can complete various basketball competitive actions better and faster.

Observations of multiple competitions after the training of the two players show that the traditional high-load strength training players who focus on limb strength training have shorter ball-handling time than the players who have undergone comprehensive training. Its ability to control the body during snatching is also relatively weak. ${ }^{11}$ This also shows that without the coordinated exertion of the whole body strength, it is more difficult for athletes to exert their strength and competitive level under the same physical conditions. It is also more difficult to occupy an advantageous position in high-intensity physical confrontation grabs.

The more scientific and effective core strength training in preventing sports injuries of athletes shows its obvious advantages. The overall training of various muscle groups of the body can promote the powerful core muscle groups of athletes to exert their strength. In this way, it can always control the various parts of the body in a suitable position during intense competition. And can help maintain the good stability of each small muscle group. ${ }^{12}$ Comprehensive training has a good protective effect on athletes' joints and other more likely to be injured in training and competition. This is a good illustration of the problem from no one injured in the 10-week training record. The traditional, more unbalanced strength training does not fully consider the coordination training of the whole body's comprehensive muscles, whether in training or connection with the competition. This also significantly increases the probability of athlete injuries.

\section{CONCLUSION}

Compared with traditional strength training, core strength training does have some advantages in certain aspects. In the actual training process, we should pay attention to core strength training in basketball teaching. While focusing on core strength training, we should not abandon traditional strength training. Load training method. At the same time, exerting the effects of traditional strength training, avoiding athletes'injuries. Through the suitable combination, better design of safe and effective training methods. Core strength training can also increase the training enthusiasm of athletes by increasing the variety of training items. At the same time, this method can promote athletes to realize their potential better.

The author declare no potential conflict of interest related to this article 


\section{REFERENCES}

1. Judge LW, Cheetham PJ, Fox B, Schoeff MA, Wang H, Momper M et al. Using sport science to improve coaching: A case study of Felisha Johnson's Road to Rio. International Journal of Sports Science \& Coaching. 2021;16(3):848-61.

2. Luczak T, Burch R, Lewis E, Chander H, Ball J. State-of-the-art review of athletic wearable technology: What 113 strength and conditioning coaches and athletic trainers from the USA said about technology in sports. International Journal of Sports Science \& Coaching. 2020;15(1):26-40.

3. Beato M, Maroto-Izquierdo S, Turner AN, Bishop C. Implementing strength training strategies for injury prevention in soccer: scientific rationale and methodological recommendations. International journal of sports physiology and performance. 2021;16(3):456-61.

4. Conti E, Ceravolo AC, Cavatton A, Quarantelli M, llika O, Varalda C. Kettlebell Sport: endurance weight lifting. Description and analysis of the performance model. Journal of Physical Education and Sport. 2020;20(5):2659-64

5. Chandrasekaran B, Fernandes S, Davis F. Science of sleep and sports performance-a scoping review. Science \& Sports. 2020;35(1):3-11.

6. Brown $\mathrm{N}$, Knight $\mathrm{CJ}$, Forrest $\mathrm{L}$. Elite female athletes' experiences and perceptions of the menstrual cycle on training and sport performance. Scandinavian Journal of Medicine \& Science in Sports. 2021;31(1):52-69.

7. Halle M, Binzenhöfer L, Mahrholdt H, Johannes Schindler M, Esefeld K, Tschöpe C. Myocarditis in athletes: a clinical perspective. European journal of preventive cardiology. 2021;28(10):1050-7.

8. Zhang Y, Popovic S, Bjelica D. Exercise core body temperature is adequately regulated following spinal cord injury: a meta-analysis. Journal of Anthropology of Sport and Physical Education. 2019;3(4):53-60.

9. Kozior M, Jakeman PM, Norton C. Peri-training nutrition methods: advancements to dietary assessment in an athletic population. Applied Physiology, Nutrition, and Metabolism. 2020;45(5):564-8.

10. Qiang J. Research on the Connotation and Implementation Path of the Fusion of Sports and Education in the New Era. Journal of Frontiers in Sport Research. 2021;1(1):6-9.

11. Arumugam J, Shaju F. To determine the relationship between anxiety and core muscle stability in rifle shooters performance. International Journal of Research and Analytical Reviews. 2019;6(2):930-3.

12. Norouzi K, Mahdavinezhad R, Mohamadi MR, Ariamanesh A. The effect of neuromuscular training on hip strength, core and jump-landing mechanics in athletes with anterior cruciate ligament reconstruction. Journal for Research in Sport Rehabilitation. 2019;7(13):77-89. 